\title{
Paper
}

\section{Three cases of Parafilaria bovicola infection in Belgium, and a few recent epidemiological observations on this emergent disease}

\author{
Y. Caron, S. Groignet, C. Saegerman, B. J. Losson
}

\begin{abstract}
Parafilariosis is a vectorborne parasitic disease caused by the development of the nematode Parafilaria bovicola in the subcutaneous and intermuscular connective tissues of cattle. On February 28, 2012, the so-called bleeding spots were observed in two heifers and one bull in a cattle herd close to Namur (Belgium). The animals had been treated in December with an injectable ivermectin/closantel solution (Closamectin pour-on, Norbrook Lab) at the recommended dosage. Samples of serohaemorrhagic exudate and blood, as well as skin biopsies, were collected. Embryonated eggs of $\boldsymbol{P}$ bovicola in the serohaemorrhagic exudate and high levels of creatine phosphokinase were detected. Clinically affected animals were treated with injectable ivermectin (Ivomec, Merial) at $200 \mu \mathrm{g} / \mathrm{kg}$. Two epidemiological phone surveys were carried out in the south of Belgium (Wallonia) in order to estimate the geographical distribution of this condition since it was first described and published in 2009. A standardised questionnaire was used and the results were analysed. Most outbreaks were recorded in the provinces of Liege and Luxembourg. The initial source of infection is still unknown, but this parasitic infection is clearly spreading from the initial Belgian outbreak site.
\end{abstract}

\begin{abstract}
Introduction
Parafilaria bovicola is a roundworm responsible for a seasonal disease characterised by the occurrence of cutaneous bleeding spots. Musca autumnalis in Europe acts as intermediate host. Economic losses due to $P$ bovicola infections in Swedish cattle were estimated to reach US $\$ 8$ million (Bech-Nielsen and others 1983). Eggs, or free L larvae, present in exudates from bleeding spots are ingested by the fly in which they develop, to $\mathrm{L}_{3}$ within several weeks. Transmission occurs when infected flies feed on lachrymal secretions or skin wounds in other cattle, and the $\mathrm{L}_{3}$ deposited then migrate in the subcutaneous tissue and develop to the adult stage under the skin in 5-7 months. Bleeding spots develop in 7-9 months after infection (Taylor and others 2007). These typical lesions facilitate the clinical diagnosis which should be confirmed by the microscopic observation of first-stage larvae in a sample of serohaemorrhagic exudate collected in sterile saline. The treatment of parafilariosis during the clinical phase relies on the use of ivermectin, moxidectin, doramectin or nitroxynil in beef and nonlactating dairy cattle (Wellington and van Schalkwyk 1982, Swan and others 1991, Gilibert 2008, Borgsteede and others 2009). Levamisole is advisable in cattle but is considered as less effective (Taylor and oth-
\end{abstract}

Veterinary Record (2012)

doi: $10.1136 /$ vr.101188

Y. Caron, DVM, MVSc,

Stéphanie Groignet, Student in

Veterinary Medicine (final year),

B. J. Losson, DVM, PhD, Dipl. EVPC,

Department of Infectious and Parasitic

Diseases, Laboratory of Parasitology and Parasitic Diseases

C. Saegerman, DVM, MSc Epi, PhD,

DipECVPH,

Department of Infectious and

Parasitic Diseases, Research Unit of ers 2007). To the authors' knowledge, no specific information is available for eprinomectin. The first two outbreaks of bovine parafilariosis in Belgium in April 2008 were described in Belgian white and blue (BWB) cattle. The absence of major clinical impact, the easy confusion with other conditions, such as accidental wounds or insect bites, and the lack of information in veterinary profession probably account for a late identification of the disease (Losson and Saegerman 2009).

\section{History and clinical examination}

On February 28, 2012, following a recent phone survey dealing with the epidemiology of cattle parafilariosis in Belgium, we were contacted by a farmer who had noticed the presence of several animals presenting bleeding spots. A visit was conducted on the farm.

Bleeding spots appeared in winter in a beef cattle herd $\left(50^{\circ} 32^{\prime} 5.77^{\prime \prime} \mathrm{N}, 4^{\circ} 46^{\prime} 40.20^{\prime}\right.$ 'E) near Namur (Saint Denis). The first bleeding spots were observed on January 10,2012. Following this first observation, there was a steady increase of clinical cases at the beginning of February; the owner estimated that about 3 per cent of his herd was clinically affected. Most of the time the lesions were located on the neck, withers, back, and thorax. The neighbouring farmers had never observed bleeding spots in their herds so far. In December 2011, as part of a routine deworming program, the animals over one year had received a pour-on application of closantel $20 \mathrm{mg} / \mathrm{kg}$ body weight and ivermectin $500 \mu \mathrm{g} / \mathrm{kg}$ body weight (Closamectin pouron, Norbrook Lab), whereas younger animals were given a pour-on formulation of ivermectin at $500 \mu \mathrm{g} / \mathrm{kg}$ (Ecomectin pour-on, Eco A $\mathrm{H}$ ), and an injection of nitroxinil at $10 \mathrm{mg} / \mathrm{kg}$ (Dovenix, Merial).

This beef cattle farm comprises 160 BWB cattle. No calves are bought in. The young bulls are the offspring of the cows and are fattened until they are sold for slaughter. At the end of February 2012, three animals presented active bleeding lesions with a serohaemorrhagic exudate: at the level of the neck and the withers of a four-yearold cow (\#9111) (Fig 1), and on the withers of a two-year-old heifer (\#9159), and on the back and upper thorax of a one-year-old bull 


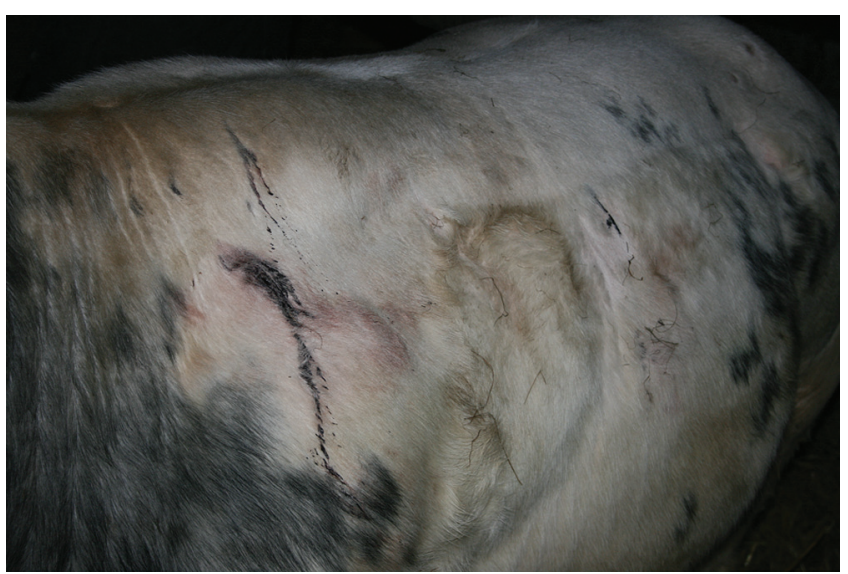

FIG 1: Serohaemorrhagic exudate on the wither of a Belgian white and blue cow

exhibiting a moderate inflammation and oedema of the thoracic area. Apart from these active lesions and some older ones characterised by a dried exudate, the clinical examination was unremarkable. The three animals were born in Belgium. Animal accommodation comprises several flattened areas and free-range pens. Animals were fed a commercial concentrate and hay.

The localisation of lesions on the upper parts of the body and the serohaemorrhagic exudate were strongly suggestive of parafilariosis, and consequently, the differential diagnosis was fairly limited. It could include insects bites (by tabanids mainly), injuries (during transport or feeding (fork)), warbles and bacterial or fungal granulomas (Table 1).

\section{Laboratory examination}

Blood samples were taken from the three animals presenting active lesions (Table 2). Creatine phosphokinase (CPK), total and differential protein levels, and the albumin/globulin ratio were measured.

Samples of serohaemorrhagic exsudate were collected from the three animals into sterile saline. At the laboratory, these samples were centrifuged for 5 minutes at $157 \mathrm{~g}$, and the pellet was transferred onto glass slides. Each sample was observed under the microscope at $\mathrm{x} 40$ magnification. Eggs with motile larvae (L1) were observed in all three samples (Fig 2).

\begin{tabular}{|c|c|c|}
\hline Agents & PRO & CONTRA \\
\hline $\begin{array}{l}\text { Parafilaria bovicola } \\
\text { (Nematoda/Filarioidae) }\end{array}$ & $\begin{array}{l}\text { Serohaemorrhagic exudate } \\
\text { lesion on upper body } \\
\text { region }\end{array}$ & $\begin{array}{l}\text { Very early (end of } \\
\text { February) }\end{array}$ \\
\hline $\begin{array}{l}\text { Hypoderma bovis (war- } \\
\text { bles) (Insecta/oestridae) }\end{array}$ & $\begin{array}{l}\text { Cutaneous nodules lesion } \\
\text { on upper body region }\end{array}$ & $\begin{array}{l}\text { No serohaemorrhagic } \\
\text { exudate }\end{array}$ \\
\hline Injuries & Lesion aspect & $\begin{array}{l}\text { No serohaemorrhagic } \\
\text { exudate }\end{array}$ \\
\hline Insect bites (Tabanidae) & $\begin{array}{l}\text { Small skin lesions with } \\
\text { bloody appearance }\end{array}$ & Season (winter) \\
\hline
\end{tabular}

TABLE 2: Blood analysis of three animals infected with Parafilaria bovicola

\begin{tabular}{lllll} 
Parameters & Cow 9111 & Heifer 9159 & Bull & $\begin{array}{l}\text { Reference } \\
\text { ranges }\end{array}$ \\
\hline $\begin{array}{l}\text { Creatine } \\
\text { Phosphokinase }\end{array}$ & $334^{* *}$ & $1438^{*}$ & $420^{* *}$ & $0-60 \mathrm{UI} / \mathrm{I}$ \\
Total serum protein & 67 & 66 & 60 & $67-76 \mathrm{~g} / \mathrm{I}$ \\
Albumin & $46.5^{*}$ & $46.7^{*}$ & $45.7^{*}$ & $55.8-66.1 \%$ \\
$\alpha-1$ zone & $0.7^{* *}$ & $0.6^{* *}$ & $0.6^{*}$ & $2.9-4.9 \%$ \\
$\alpha-2$ zone & $17.7^{*}$ & $19.2^{*}$ & $19.6^{*}$ & $7.1-11.8 \%$ \\
$\beta$ zone & $7.5^{* *}$ & $7.3^{*}$ & 9.4 & $7.9-13.7 \%$ \\
Albumin/globulin ratio & $0.87^{*}$ & $0.88^{*}$ & $0.84^{*}$ & $1.2-2$ \\
\hline
\end{tabular}

"Out of range

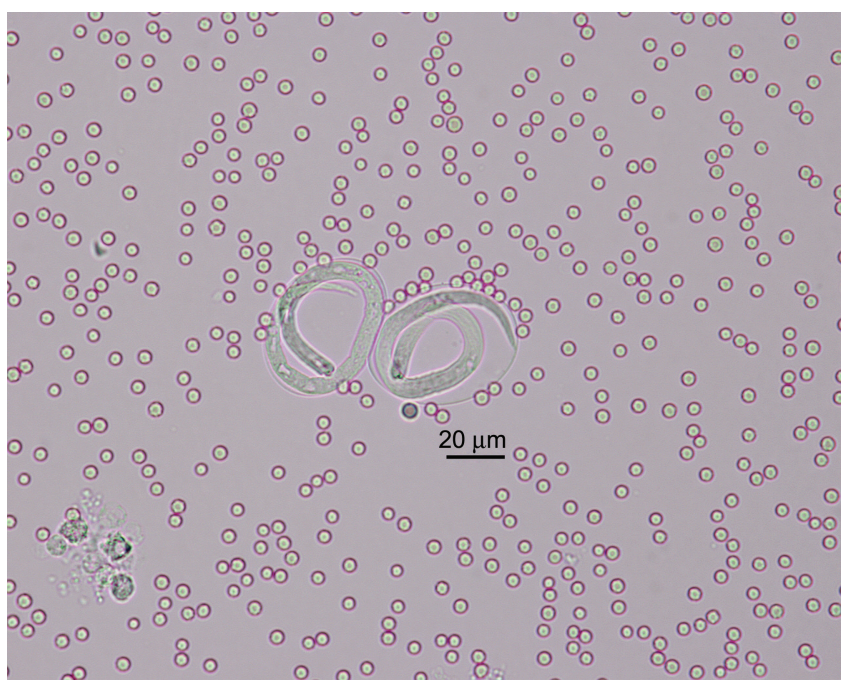

FIG 2: Two embryonated eggs of Parafilaria bovicola in serohaemorrhagic exudate; unstained preparation

Several biopsies were realised at the level of the cutaneous nodules and intermuscular connective tissue. They were fixed in formaldehyde, embedded in paraffin wax, cut with a microtome and stained. A haemorrhagic, perivascular and acute inflammatory infiltrate in connective tissue was observed, but unfortunately, no transverse section of the worm was visible. This infiltrate was principally constituted of eosinophils (Fig 3). Parafilariosis, due to $P$ bovicola was diagnosed. The prognosis was considered as good.

\section{Control and outcome}

Pour-on applications of closantel $20 \mathrm{mg} / \mathrm{kg}$ body weight, and ivermectin $500 \mu \mathrm{g} / \mathrm{kg}$ body weight (Closamectin pour-on, Norbrook Lab) were given by the vet to the three animals at the end of February.

As the bleeding spots were still active one week later, a subcutaneous injection of ivermectin $200 \mu \mathrm{g} / \mathrm{kg}$ body weight (Ivomec, Merial) was given, and the skin regained its normal appearance two weeks later; no other lesions were recorded thereafter.

\section{Epidemiological survey}

The 43 vets contacted during a previous study in Belgium (Losson and Saegerman 2009) were contacted again in 2011 in order to collect additional information on the potential spreading of parafilariosis in Wallonia between 2008 and 2011. Unfortunately, only 29 were still active in large animal practice in 2012. In 2008, 37 per cent (16/43) of them had observed clinical signs of parafilariosis (Losson and

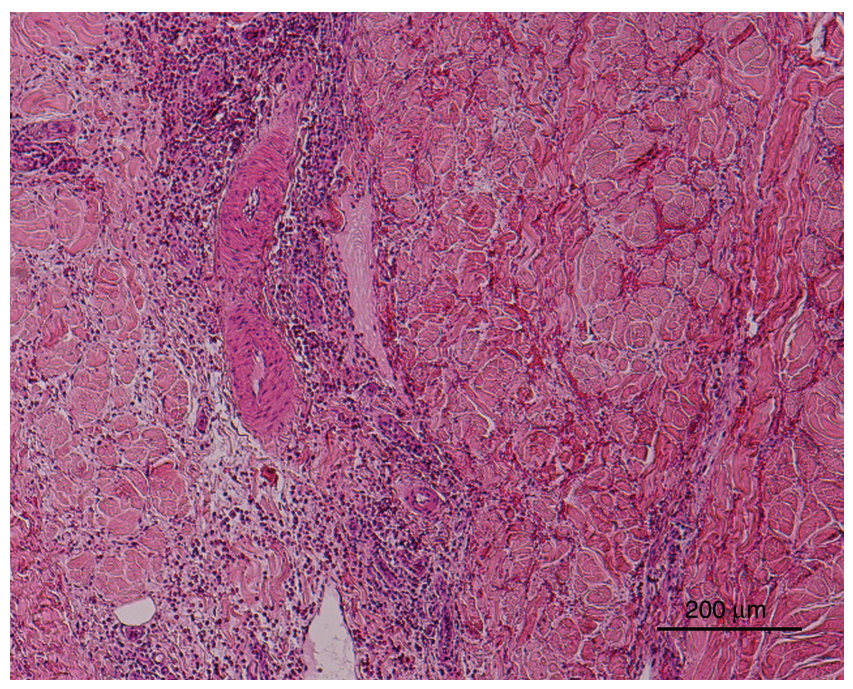

FIG 3: Haemorrhagic and acute inflammatory infiltrate in connective tissue (H\&E stain) 
Saegerman 2009). The incidence reached 42 per cent (18/43), 24 per cent (8/29) and 31 per cent (9/29) in 2009, 2010 and 2011, respectively. Thirty-eight per cent (11/29) of the contacted vets had not seen the disease between 2009 and 2011, whereas 14 per cent (4/29) of them observed it every year since 2009. Additionally, 118 other vets, active in large animal practice, were contacted by phone in 2011 and at the beginning of 2012. The questionnaire focused, among others, on the following points: have they ever seen parafilariosis? In 2011/2012? How many outbreaks in 2011/2012, and where? The type of animals (heifer, cow, bull)? Did they treat? What drug was used? What was its efficacy? Thirty-two per cent (38/118) of the vets had never seen this condition before 2011, but only 19 per cent (22/118) in 2011/2012 had. Fig 4 illustrates the localisation of the 118 contacted vets in Wallonia, and the number of outbreaks (59) they recorded in 2011 and at the beginning of 2012. Thirty-two per cent $(12 / 38)$ of animals were bulls and 68 per cent $(26 / 38)$ were cows or heifers. About one-third of the vets (10/32) did not treat the condition, whereas the remaining two-thirds used different macrocyclic lactones under different formulations (pour-on, injectable), such as ivermectin (20/22) and doramectin (2/22)) with an estimated clinical efficacy of 100 per cent.

Considering the vets from the province of Hainaut as the reference group, the vets coming from the provinces of Liege (OR $=39$; 95\% CI 5 to 325$)$ and Luxembourg $(O R=15 ; 95 \%$ CI 2 to 135$)$ were more likely to find parafilariosis.

\section{Discussion}

In accordance with the random phone survey across the southern part of Belgium, parafilariosis was more frequently observed in vets working in the provinces of Liege and Luxembourg. This is in accordance with previous findings (Losson and Saegerman 2009).

In terms of diagnosis, the blood analysis was not very useful for several reasons. First it would have been interesting to compare the different parameters with those obtained from BWB cattle from a farm free of parafilariosis. Indeed it is commonly admitted that BWB cattle have different reference ranges for different parameters, such as CPK. This is due to the fact that BWB cattle have a particularly developed muscular mass when compared with other breeds, such as HolsteinFriesian, and even Charolais and, consequently, physiological CPK values are higher in these breeds. Nevertheless, an increase of CPK during active parafilariosis is probably linked to a marked inflammatory response at the muscular level. Additionally, the increase of the $\alpha-2$ zone is indicative of an acute inflammatory phase response (haptoglobin, eg, is an $\alpha-2$ protein). However, because of the long prepatent period (7-9 months) parafilariosis is more a chronic condition than an acute one. Moreover, very little is known about the potential pathological effects of the migrating larvae. An increase of blood eosinophilia of infected cattle was previously described (Hamel and others 2010). In the present cases, this was not the case. However, the histopathological examination revealed a marked tissue infiltration composed mainly of eosinophils.

Injectable macrocyclic lactone seems more efficient than pour-on formulations, as previously recorded for moxidectin (Borgsteede and others 2009). This study seems to confirm the poor efficacy of macrocyclic lactones administered during the migrating larval phase (Taylor and others 2007). If this is confirmed, this would greatly complicate the control of the disease which seems on the rise in Belgium, as four out of five provinces in Wallonia are infected. Furthermore, the muscid fly vector (the face fly, $M$ autumnalis) is widespread in Europe and extremely common outdoors. Use of insecticide-impregnated ear tags (Borgsteede and others 2009), or dipping with deltamethrin (Nevill and others 1987), were recommended for vector control.

It is noteworthy, that in the present infected farm, the first bleeding spots were recorded very early on January 10,2012. At this period of the year, fly activity is usually very low although $M$ autumnalis is able to overwinter as adult flies. Indeed, only one veterinary practitioner reported bleeding spots in February in Belgium in 2008 although most cases were observed in April-May (Losson and Saegerman 2009). At this time of the year, cattle are usually on pasture, and clinical cases could be easily overlooked, this in turn could further complicate the control of the disease.

The introduction of $P$ bovicola in Belgium could be related to the importation of infected cattle from France, as was described in Canada (Webster and Wilkins 1970), in Sweden (Lundquist 1983), in Ireland (Torgersen and others 1998) and in The Netherlands (Borgsteede and others 2009). It seems that $P$ bovicola is now endemic in Belgium and Germany (Hamel and others 2010). Additional information should be collected from Flanders (north of Belgium), where a bull imported in 2008 from Wallonia (South of Belgium) was infected

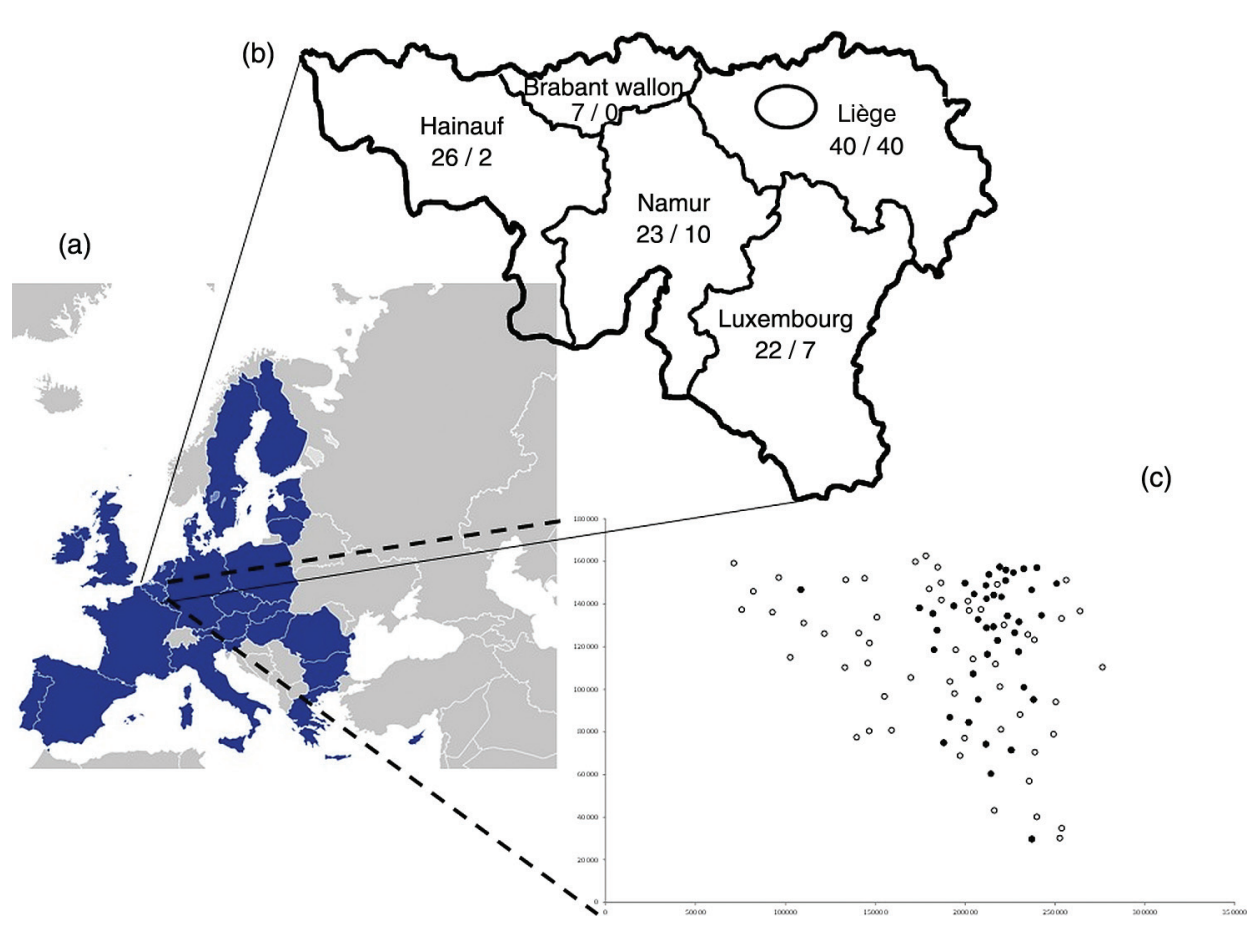

FIG 4: Study area (A) and localisation of the 116 veterinarians contacted in 2011 in Wallonia (B). The number of contacted vets/the number of parafilariosis outbreaks were mentioned in regard to each province. The black ellipse indicates the localisation of the first published outbreaks (2009). All communes investigated were mentioned by a circle, and each black circle corresponds to the presence of parafilariosis in a specified commune (C) 
with P bovicola (Pardon and others 2010). Furthermore, prophylactic usefulness of macrocyclic lactones should be further investigated.

\section{Acknowledgements}

Thanks to all veterinarians who were involved with this study.

\section{References}

BECH-NIELSEN, S., HUGOSON, G. \& WOLD-TROELL, M. (1983) Economic evaluation of several control programs for the cattle nematode Parafiliria bovicola using benefitcost analysis. Preventive Veterinary Medicine 1, 303-320

BORGSTEEDE, F. H., VAN WUIJCKHUISE, L., PEUTZ, J., ROUMEN, T. \& KOCK, P (2009) Import of Parafilaria bovicola in the Netherlands. Veterinary Parasitology 161, 146-149 GILIBERT, S. (2008) Les affections cutanées de la mamelle et du trayon chez la vache Lyon: University Claude-Bernard - ENV. p 195

HAMEL, D., AXT, H. \& PFISTER, K. (2010) First report on Parafilaria bovicola (Nematoda: Filaroidea) in Germany. Research in Veterinary Science 89, 209-211

LOSSON, B. \& SAEGERMAN, C. (2009) First isolation of Parafilaria bovicola from clinically affected cattle in Belgium. Veterinary Record 164, 623-626
LUNDOUIST, H. (1983) Parafilaria bovicola (Tubangui 1934) established in Swedish cattle Nordisk Veterinaermedicin 35, 57-68

NEVILL, E. M., WILKINS, C. A. \& ZAKRISSON, G. (1987) The control of Parafilaria bovicola transmission in South Africa. Onderstepoort Journal of Veterinary Research 54 547-550

PARDON, B, ZWAENEPOEL, I, VERCAUTEREN, G, CLAEREBOUT, E. \& DEPREZ, P. (2010) Parafilariasis in a Belgian Blue breeding bull in Flanders. Vlaams Diergeneeskundig Tijdschrift 79, 54-58

SWAN, G. E., SOLL, M. D. \& GROSS, S. J. (1991) Efficacy of ivermectin against Parafilaria bovicola and lesion resolution in cattle. Veterinary Parasitology 40, 267-272

TAYLOR, M. A., COOP, R. L. \& WALL, R. L. (2007) Parasites of cattle. In Veterinary Parasitology. Eds M. A. TAYLOR, R. L. COOP, R. L. WALL. Blackwell Publishing. pp 129-130

TORGERSEN, P. R., DOHERTY, M. L. \& HEALY, A. M. (1998) Bovine haemorrhagic parafilariosis in an imported Charolais bull. Irish Veterinary Journal 51, 27-29

WEBSTER, W. A. \& WILKINS, D. B. (1970) The recovery of Parafilaria bovicola Tubangui, 1934 from an imported Charolais bull. Canadian Veterinary Journal 11, 13-14

WELLINGTON, A. C. \& VAN SCHALKWYK, L. (1982) The effect of a single injection of nitroxynil at $20 \mathrm{mg} / \mathrm{kg}$ live mass in the treatment of Parafilaria bovicola infestations in cattle. Journal of the South African Veterinary Association 53, 91-94 


\title{
veterinary Three cases of Parafilaria bovicola infection in Belgium, and a few recent epidemiological observations on this emergent disease
}

\author{
Y. Caron, S. Groignet, C. Saegerman, et al. \\ Veterinary Record published online December 21, 2012 \\ doi: 10.1136/vr.101188
}

Updated information and services can be found at:

http://veterinaryrecord.bmj.com/content/early/2012/12/20/vr.101188.full.html

\begin{abstract}
References This article cites 11 articles, 1 of which can be accessed free at: http://veterinaryrecord.bmj.com/content/early/2012/12/20/vr.101188.full.html\#ref-list-1

$\mathbf{P}<\mathbf{P} \quad$ Published online December 21, 2012 in advance of the print journal.
Email alerting
Receive free email alerts when new articles cite this article. Sign up in service the box at the top right corner of the online article.
\end{abstract}

\section{Notes}

Advance online articles have been peer reviewed, accepted for publication, edited and typeset, but have not not yet appeared in the paper journal. Advance online articles are citable and establish publication priority; they are indexed by PubMed from initial publication. Citations to Advance online articles must include the digital object identifier (DOIs) and date of initial publication.

To request permissions go to:

http://group.bmj.com/group/rights-licensing/permissions

To order reprints go to:

http://journals.bmj.com/cgi/reprintform

To subscribe to BMJ go to:

http://group.bmj.com/subscribe/ 